\title{
THE INDONESIAN CONSTITUTION READ WITH GERMAN EYES
}

\author{
Herbert Küpper * \\ Institute for East European Law Munich, Germany \\ herbert.kuepper@ostrecht.de
}

Received: 4 April 2020 | Last Revised: 8 December 2020 | Accepted: 25 March 2021

\begin{abstract}
The Indonesian Constitution offers many interesting insights to a German constitutional scholar. The most striking feature is the balance between the unitarian state and the natural diversity of Indonesia. In Germany, the state architecture reflects regional diversity in its federal framework, whereas Indonesia combines the unitarian state with various decentralising elements. This balance between unitarianism and regional diversity is probably the most conspicuous feature of the Indonesian Constitution and appears to be a suitable compromise between the conflicting aims of stabilising the state and the nation on the one hand and accommodating the geographic, demographic and cultural differences within the country on the other. Another striking feature is the presidential system, which is quite the opposite of the parliamentary system of the German Constitution. Other points that, from the perspective of German constitutional law, invite comparison are the constitutional provisions about the legal system, Indonesia's constitutional monotheism, which is quite the opposite of the German idea of the state being strictly neutral in religious affairs, and human rights.
\end{abstract}

Keywords: German Constitution, Human Rights, Indonesian Constitution, Legal System, Unitarian State.

Director of the Institute for East European Law, Munich, Germany (www.ostrecht.eu), Professor of the Andrássy Gyula University, Budapest, Hungary, Vice-President of the German Association of South East European Studies, Member of the Academic Consultative Board of the President of the Hungarian Constitutional Court, former Member of the Academic Board of the Research Centre of Social Sciences of the Hungarian Academy of Science. 


\section{INTRODUCTION}

It is a truism that when you compare your law with foreign law, you learn most about your own law. Thus, when I studied the Indonesian Constitution, I learnt much about German constitutionalism, for which I am very grateful. With this paper, I would like to give something back to the Indonesian legal public and share some of the thoughts a German lawyer has when reading the text of the Indonesian Constitution. ${ }^{1}$ Insofar, I apply the comparative method: I read a foreign constitution through the lens of German constitutional doctrine. This paper concentrates on the text of the Constitution, and I deliberately leave aside a deeper analysis of the pertinent Indonesian constitutional practice. The reason is that every knowledge of the law, including constitutional law, starts with the text of the normative act. This method is valid for comparative studies as well.

With this paper, I do not want to question the choices the Indonesian Constitution makes. Indonesia is a sovereign country and free to take its own constitutional decisions. There is no point in advertising 'German solutions' for Indonesian problems. My purpose is much rather to point at some features of the Indonesian Constitution that strike a reader with a German constitutional background, to lend an Indonesian reader the external perspective on the Indonesian Constitution that a German lawyer has. ${ }^{2}$ Both German and Indonesian constitutional cultures can learn from each other, and with this paper, I would like to contribute to Indonesian-German comparative constitutional studies.

\footnotetext{
The basis of this paper is the English translation of the consolidated version of the Constitution of the State of the Republic of Indonesia of the year 1945, including the fourth amendment, published by The Office of the Registrar and the Secretariat General of the Constitutional Court of the Republic of Indonesia (ed.), The 1945 Constitution of the Republic of Indonesia, Law of the Republic of Indonesia concerning the Constitutional Court (Jakarta: The Constitutional Court of the Republic of Indonesia, 2015). Where the English translation seemed unclear, I reverted to the original version of the Constitution, published on the website of the Constitutional Court of the Republic of Indonesia: "Undang-undang Dasar Negara Republik Indonesia Tahun 1945 [The 1945 Constitution of the Republic of Indonesia]," accessed January 28, 2021, https://jdih.mkri.id/mg58ufsc8ghrsg/ UUD_1945_Perubahan.pdf.

2 A first German view on the Indonesian Constitution was presented by Karl Bünger, "Dokumente zur Entstehung der Vereinigten Staaten von Indonesien [Documents on the Creation of the United States of Indonesia]," Zeitschrift für ausländisches öffentliches Recht und Völkerrecht [Heidelberg Journal of International Law] 13 (1950): 431-473, https://www.zaoerv.de/13_1950_51/13_1950_2_b_431_473.pdf.
} 
The comparison of the Indonesian Constitution of 1945 and the German Constitution of 1949, the so-called Grundgesetz (Basic Law), ${ }^{3}$ offers insights in many fields of constitutional law. However, this paper cannot give an overall comparison between Indonesian and German constitutional law, but concentrates on some aspects that I find most striking: the balance between the unitarian state and the natural geographic and demographic diversity of Indonesia's huge archipelago, the presidential system, the provisions on the legal system, democracy, constitutional monotheism, and human rights. Finally, I shall deal with technical issues such as the repetitiveness of some parts of the text and its terminological diversity.

This choice may appear to be rather random. There are many features in the Indonesian and German constitutions that invite and necessitate a comparative analysis. Yet, the limited space available requires a selection. I chose the topics that most strongly arouse my curiosity. At first sight, curiosity is not a scientific category. Yet, it is the - admittedly subjective - starting point for all acquisition of knowledge. In the field of comparative law, curiosity is usually aroused by 'otherness'. ${ }^{4}$ This 'otherness' between the Indonesian and the German Constitutions is most distinct in the issues I address: the organisation of territory and diversity, the governmental system, the legal system, democracy, and the role of human rights in general and religion in particular. Their tertium quid comparatist is that all these issues address, in both constitutions, fundamental political self-definitions and/or solutions for actual or bygone societal conflicts. The answers in Indonesia and Germany are sometimes different and sometimes run parallel and thus invite comparison.

\section{ACCOMMODATING TERRITORIAL AND DEMOGRAPHIC DIVERSITY}

Indonesia's territory consists of a large number of islands, as Article $25 \mathrm{~A}$ of the Indonesian Constitution acknowledges. These islands harbour numerous

\footnotetext{
"Basic Law for the Federal Republic of Germany of 23 May 1949," Translation, accessed January 28, 2021, https:// www.gesetze-im-internet.de/englisch_gg/.

4 Uwe Kischel, Rechtsvergleichung [Comparative Law] (Munich: C.H. Beck, 2015), 1-27.
} 
cultures, languages, religions, social and economic systems, ranging from the stone age to the $21^{\text {st }}$ century. It is obvious that the heterogeneity of these natural features creates a unique challenge for state-building. For Indonesian constitution-makers, this probably has been the most demanding challenge.

Dutch rule had reacted to this challenge with a mixture of centralisation of power and administrative neglect of the economically less interesting parts of the colony. This mixture was typical for European colonial systems but was, naturally, no basis on which to build an independent Indonesian state. Instead, the Indonesian Constitution of 1945 creates a fine balance between centralisation and decentralisation.

\subsection{The Unitarian State}

First, there is the basic choice in favour of a unitarian state. In a German understanding, Indonesia with its geographical and demographic diversity would be an ideal candidate for a federal system. As a matter of fact, Indonesia became independent as the "Republic of the United States of Indonesia". ${ }^{5}$ The federal structure was not an original idea of the Indonesian independence movement but a reaction to Dutch and American wishes, and when Indonesia in 1950 felt strong enough to ignore these international wishes, it reverted to the unitarian state. After independence, a major concern was keeping the newly created country together. In such a situation, dropping federalism if it does not have any local traditions and choosing the centralist way of a unitary state seems an expedient option. Therefore, the founding fathers of the Indonesian Constitution made the unitary state [Negara Kesatuan] the central feature of the new Indonesian statehood, as it is set out most prominently in article $1(1)^{6}$ and $25 \mathrm{~A}$. Furthermore, the unitary state is one of the two constitutional principles that article 37(5) protects against future amendments. ${ }^{7}$ This is in line with

Charter of Transfer of Sovereignty of 27 December 1949.

Articles without any further qualification are those of the Constitution of Indonesia.

Comparative constitutionalism shows that quite a few 'eternity clauses' enumerate not only the articles or principles which cannot be amended, but also the 'eternity clause' itself in order to prevent that in a first step the eternity clause is changed and in a second step the protected article or principle: Peter Häberle, "Verfassungsrechtliche Ewigkeitsklauseln als verfassungsstaatliche Identitätsgarantien [Constitutional Eternity Clauses as Guarantees 
the five foundational principles of Indonesia, Pancasila, as enshrined in the Preamble of the Indonesian Constitution: its third principle advocates the unity of Indonesia (Persatuan Indonesia).

However, the principle of the unitary state is not the ultimate word but only the starting point of balancing centralism with regionalism and decentralisation. The unity of Indonesia in Pancasila aims at keeping the country together but does not require necessarily a unitarian, let alone a hyper-centralised state. It accommodates any solution that balances regional and other diversity and the integrity of the Indonesian state. ${ }^{8}$ Many constitutional provisions relate to this balance, putting the principle of the unity of Indonesia at the core of constitution-making as well as state- and institution-building. This is a contrast to Germany, where the strong regional identities have ceased to question the existence of the overarching German state since the $19^{\text {th }}$ century. Regional identities are accommodated, at least partly, by a federal state structure which is seen as a guarantee and not as a danger for the acceptance of the German state.

\subsection{Elements of Centralisation and Decentralisation in the Highest State Organs}

In the state structure, we find elements of both centralisation and decentralisation. This starts at the very top, with the President. As a oneperson organ ${ }^{9}$ elected directly by the people, the President symbolises the entire Indonesian state and nation and their unity. Therefore, the

of Constitutional Identity]," in Völkerrecht im Dienste des Menschen [International Law Serving Man], ed. Yvo Hangartner and Stefan Trechsel (Bern: Haupt, 1986), 81-108; Bernd Wieser, Vergleichendes Verfassungsrecht [Comparative Constitutional Law] 2 ${ }^{\text {nd }}$ ed (Vienna: Verlag Österreich, 2020), 123-127. The German Grundgesetz, however, is just like the Indonesian Constitution. Art. 79(3) of the German Grundgesetz and art. 37(5) of the Indonesian Constitution forbid expressly only the change of the protected articles and principles, but not their own amendment. In Germany, it is accepted that art. 79(3), too, is exempt from amendments: Federal Constitutional Court, decision of 23 April 1991, 1BvR 1170, 1174, 1175/90, at C.Il.2., available at https://www.servat.unibe.ch/dfr/ bv084090.html. Accessed January 28, 2021. The same probably applies to Indonesia: Luthfi Widago Eddyono, "The Unamendable Articles of the 1945 Constitution," Constitutional Review 2, no. 2 (2016): 252-269.

8 Tedi Sudrajat, "Harmonization of Regulation Based on Pancasila Values Through the Constitutional Court of Indonesia," Constitutional Review 4, no. 2 (2018): 301-325; Ken Ward, "Soeharto's Javanese Pancasila," in Soeharto's New Order and its Legacy: Essays in honour of Harold Crouch, ed. Edward Aspinall and Greg Fealy (Canberra: ANU Press, 2010), 27-37.

9 The Vice President is, according to art. 4(2), a mere assistant. Therefore, the office of the Vice President does not question the one-person nature of the presidential office. 
President as such is a centralising factor. However, there are some elements of decentralisation in the constitutional provisions about the President, too. For the presidential elections, article $6 \mathrm{~A}(3)$ requires not only an absolute nation-wide majority but also a certain geographical distribution of the votes. On a comparative basis, clauses on a balanced geographical distribution are more frequent for referenda ${ }^{10}$ than for the election of political representatives. They want to guarantee that the referendum's goal is embraced in the entire country and not only in the demographic majorities or other population centers. In Indonesia, this logic ensures that the President is the representative of the entire country and not only of one geographical part of it. Especially Java cannot convert its demographic majority easily into forcing a 'Javanese' candidate upon the country, but the candidate has to be acceptable everywhere in the country. However, this protection holds only in the first round because if there is a second round between the two most successful pairs of candidates, article $6 \mathrm{~A}(4)$ lets a simple nation-wide majority suffice, without regional safeguards.

Parliament, too, possesses centralising and decentralising features. Due to its nation-wide elections [article 19(1)], the People's Representative Council represents the entire people in a uniform way and is therefore a centralising factor in the state architecture. This is somewhat counterbalanced by the Regional Representative Council, where every province is represented by an equal number of elected members [article $22 \mathrm{C}(1)-(2)]$. The People's Representative Council of the second chambers of federal systems which are designed to give the federal units a forum in the national parliament. One possible model of the membership in such a federal second chamber is the numerically equal representation of all federal units, e.g., in the US Senate, where every state has two senators or in Switzerland, where every canton is represented by two representatives in the second chamber.

A European Citizens' Initiative can be initiated by persons residing in at least seven different EU member states: Regulation (EU) 2019/788 of the European Parliament and of the Council of 17 April 2019 on the European citizens' initiative, see "Regulation (EU) 2019/788 of the European Parliament and of the Council," Eur-Lex, accessed January 28, 2021, https://eur-lex.europa.eu/legal-content/EN/TXT/?uri=CELEX\%3A32019Ro788\&qid=1611135454353. 
The federal chamber of the German parliament, the Bundesrat [Federal Council], follows a different model because the various states are granted between three and six members, according to their number of inhabitants. " For Indonesia, the American or Swiss idea of a numerically equal representation seems more appropriate because it favours the sparsely populated regions and prevents a possible dominance of Java with its demographic majority. In the need to balance regional diversity against a demographically, politically and economically dominant 'central' people, Indonesia is similar to India, where especially the Dravidic south, but also the Marathi, Bengal, Punjabi, Gujarati and other peoples resent the dominance of the 'Hindi heartland', which they perceive as aggressive and potentially assimilating. However, India chose for its federal chamber, the Rajya Sabha, an imperfect proportional composition similar to the German Bundesrat: the federal states and territories have a number of representatives weighed according to the number of inhabitants, though it does not reflect the demographic differences to their full extent. In my view, the Indonesian Regional Representative Council, with its equal number of representatives for each province, is better equipped to balance regional differences and the natural overweight of the 'Javanese heartland', and therefore is better able to preserve inter-regional and inter-ethnical peace in a country as diverse as Indonesia. It has to be noted, however, that the composition of the Regional Representative Council does not reflect the democratic principle of the equality of votes because the sparsely populated regions are overrepresented. This democratic 'flaw' is accepted in many states in order to achieve other political goals such as a political accommodation of regional differences, like in the German Bundesrat. This 'democratic imperfection' of the second chamber is counterbalanced by a first chamber based on

The scale between three and six members reflects the demographical differences only imperfectly because the number of inhabitants of the federal states ranges from 700,000 to 18 million. German doctrine qualifies it as a mixture of the federal principle (equal representation for all federal units) and the demographic principle. For more detail, see Uwe Jun, "Der Bundesrat im föderativen System Deutschlands: Vor und nach der Reform 2006 [The Federal Council in Germany's Federal System: Before and After the Reform of 2006]," in Analyse demokratischer Regierungssysteme [Analysis of Democratic Systems of Government], ed. K. H. Schrenk and M. Soldner (Wiesbaden: Verlag für Sozialwissenschaften, 2010), 335-358. 
universal and equal ballot. Also, the European Parliament is not based on the equal weight of all votes because small member states have more seats per capita than the larger member states; ${ }^{12}$ this is accepted because the European Parliament is not the representative of a uniform 'European people' but of the member states.

Looking at the distribution of powers between the People's Representative Council and the Regional Representative Council, all substantial powers such as legislation, control of the executive or elections of high state representatives are vested in the People's Representative Council. The powers of the Regional Representative Council concentrate on issues of regional and other diversity, which very wisely include aspects of economy and the central budget and taxes [article 22D, 23(2)]. These powers are merely consultative. The Regional Representative Council cannot take decisions of its own, and it does not even have a suspensive veto in the matters it needs to be consulted about. Insofar, it is not a 'real' second chamber and resembles most the Slovenian State Council, which, with merely consultative powers, represents regional and professional interests. ${ }^{13}$ In Germany, the only consultative second chamber, the Senate in the federal state of Bavaria, was abolished by referendum in 1999. The Bundesrat may veto any bill, but may be overridden in the first chamber; its assent is necessary only in the cases enumerated in the Grundgesetz, mostly administrative legislation.

\subsection{Regional Government and other Decentralising Factors}

The strongest decentralising element in the Indonesian state architecture is probably regional government. Regional governments have a democratic basis with some sort of separation of powers [article 18(3)-(4)] and enjoy autonomy in their local and regional affairs, as article 18(2) sets out. The guarantee function of article 18(2), however, is quite weak because it does not define what "their own government affairs" [urusan pemerintahan mereka

${ }_{12}$ In the European Parliament with 705 members, the 83 million inhabitants of Germany are represented by 96 MPs and the 520,000 inhabitants of Malta by 6 MPs As a result, a Maltese vote carries ten times more weight than a German vote.

13 Constitution of the Republic of Slovenia of 23 December 1991, arts. 96-101. 
sendiri] are. This term is open to interpretation, and an aggressive central government could easily argue that most public affairs belong to the central and not to the regional government. If article 18(2) contained an open list of examples of the matters that constitute "their own government affairs", as many constitutions do in their protection clauses on the autonomy of local government, it would be more difficult for the central government or the central law-maker to interfere in regional affairs. The German example shows that also the courts can help. The constitutions of most federal states protect local autonomy with a formula similar to article 18(2), granting them the right to regulate and administer "local affairs". Numerous decisions by constitutional and administrative courts quashed federal and state laws that regulate, and executive measures that administer matters that the courts identified as local affairs, thus protecting local government against state institutions. In their wide interpretation of "local affairs", the German courts often revert to tradition. Where the tradition of local autonomy is weaker, as e.g., in Hungary, the courts take a more centralist approach: In the first thirty years of its existence, the Hungarian Constitutional Court only quashed one legal provision because it regulated a question that the court interpreted as a "local affair". ${ }^{14}$

In Indonesia, article 18(2) is helped by article 18(5) granting regional governments "widest autonomy" which comprises everything except what the law defines as "affairs of the Central Government". This can be read as a constitutional presumption in favour of regional powers. ${ }^{15}$ Yet, the protection that article 18(5) affords is weak, too. If article 18(5) did not leave it to the law - and thus, indirectly, to the Central Government - to define what "Central Government affairs" [urusan Pemerintah Pusat] are, and if that provision itself gave an essential definition of Central Government

${ }_{14}$ For a comparison of the pertinent practice of the German and Hungarian constitutional courts see Herbert Küpper, Autonomie im Einheitsstaat [Autonomy in a Unitarian State] (Berlin: Duncker\&Humblot, 2002), $185-188$.

15 Art. 30 Grundgesetz establishes a presumption in favour of the federal states: the federation may act only if the Grundgesetz itself refers a given matter to federal jurisdiction, and the states are free to exercise any competence not expressly reserved for the federation. 
affairs, it would guarantee the essence of regional autonomy to a stronger degree than it does now.

Another decentralising factor in this respect is article $18 \mathrm{a}(1), 18 \mathrm{~b}(1)$ which call for respect of regional specificities. Thus, the system of regional governments does not need be uniform throughout Indonesia but may and must accommodate regional differences. The regional government in Aceh may have structures different from those in Central Java, Maluku and/or West Papua. Similarly, in Germany, each federal state has its own system of central and local government, the homogeneity clause in article 28(1) Grundgesetz only demanding that state and local governments be republican, democratic, social and obey the rule of law. Until now, there has been no precedent that structures in a federal state did not conform to these principles, i.e., the diversity on the state level never jeopardised the uniformity of the basic traits. If a federal state violated one of these basic principles, the Federal Constitutional Court could intervene and, if this did not help, the state may be placed under direct federal administration, as article 37 Grundgesetz sets out. ${ }^{16}$ The Indonesian Constitution does not provide for similar safeguards. The reason is that the German 'duty to homogeneity' in article 28(1) focuses on the federal states, defining a framework for their organisational autonomy. In Indonesia, on the other hand, articles $18 \mathrm{~A}(1)$ and $18 \mathrm{~B}(1)$ do not regulate the political space of the regional level but of central legislation.

Regional governments are strengthened by the fact that their scrutiny by the independent Financial Audit Board bears decentralised features. This Board has a decentralised structure in itself because it is present in every region [article $23 \mathrm{G}(1)$ ], and for this reason it makes sense that the Regional Representative Council is consulted before the election of the members of the Board [article 23F(1)].

${ }_{16}$ Falk Schöning, Föderale Intervention als Instrument zur Bewahrung eines Bundesstaates - Rechtsvergleichende Analyse und völkerrechtliche Legitimation [Federal Intervention as an Instrument to Preserve a Federal State Comparative Analysis and Legitimacy in International Law] (Baden-Baden: Nomos, 2008). 
Finally, the respect for traditional societies in article 28I(3) and for adat (indigenous) law societies in article $18 \mathrm{~B}(2)$ is another decentralising factor although the wording of these provisions is conditional (not rather reluctant). Traditional societies, which are usually vulnerable, are protected only to the extent that they are "in harmony with ... civilisation", which may be bad news for stone age cultures and their traditional land rights if they are not recognised as "civilisation". Furthermore, the state "respects" "existing" adat societies meaning that there is no duty for the state to actively support them. Article $18 \mathrm{~B}(2)$ suggests that the state must not actively destroy adat societies but may patiently wait until they find a natural end, e.g., through assimilation or social development. ${ }^{17}$ In Germany, there are no 'traditional societies', so the problem does not arise. The constitutions of the federal states with ethnic minorities grant them special cultural rights and oblige the state to promote minority culture.

\subsection{Centralising Elements}

Centralising elements are the symbols of the central state (articles 35, 36A, 36B) and Bahasa Indonesia (article 36). Also, the idea of "Indonesia's national culture" in article 32(1) has a centralising tendency even if this national culture is interpreted as being composed of a large number of regional cultures, including traditional and adat societies. One of the strongest unifying effects may be the "one" (satu), i.e., uniform national educational system [article 31(3)] with its goal to foster "national unity" [article 31(5)]. For this very reason, the German federal system refers culture and education into the jurisdiction of the federal states, with the federation having only very limited powers in this field (article 30 Grundgesetz). This is to guarantee the preservation and advancement of regional cultural diversity which a decentralised school system passes on to the next generations. Culture and education are bulwarks of decentralisation in Germany, whereas they tend to contain centralising elements in the Indonesian Constitution.

\footnotetext{
${ }_{17}$ I Nyoman Nurjaya, "Is the Constitutional And Legal Recognition Of Traditional Community Laws Within The Multicultural Country Of Indonesia A Genuine Or Pseudo Recognition?" Constitutional Review 1, no. 2 (2015): 49-68.
} 


\subsection{The Balance between Centralism and Decentralisation}

In sum, the central elements appear stronger than the decentralising ones. This is no surprise because that is the reality in most countries of the world. Even federal systems find that their federalism does not protect them from developing an increasingly centralist political culture. ${ }^{18}$

As a German, one feels inclined to propose a strengthening of the decentralising factors, an upgrading of regional government, perhaps even into some mild form of federalism. ${ }^{19}$ From a German perspective, Indonesia with its geographical and cultural diversity would be ideal for a federal system. Germany has had quite positive experiences with decentralisation and federalism for nearly 1,00o years. German federalism is not based on ethnic differences because - leaving a few minorities and immigrants aside - the German people are ethnically quite homogeneous. There are, however, strong regional identities in Germany, and most dialects of German cannot be understood outside their region. Yet, the borders of the federal states are rarely identical with the territories of regional identities and/or dialects. Hence, German federalism is not an ideal instrument to represent regional identities and does not bear the danger of ethnic or other separatism. One positive effect of federalism - apart from an additional system of checks and balances, which is a value in itself $^{20}$ - is that cultural and economic life is not concentrated in the capital city and not even in the big cities

18 For German federalism, the first such in-depth diagnosis was given by Konrad Hesse, Der unitarische Bundesstaat [The Unitarian Federal State] (Karlsruhe: C.F. Müller, 1962).

19 Therefore, German authors who publish on Indonesia's constitutional system usually draw a positive balance of efforts to decentralise the country: Franz von Benda-Beckmann, "Verfassungsrechtspluralismus in West Sumatra: Veränderungen in staatlicher und dörflicher Verfassung im Zuge der Dezentralisierung in Indonesien [Constitutional Pluralism in West Sumatra: Changes in the Constitution of the State and of the Villages in the Course of Decentralisation in Indonesia]," Verfassung und Recht in Übersee [Law and Politics in Africa, Asia and Latin America] 35, no. 4 (December 2002): 494-512; Hannah Neumeyer, "Unity in Diversity or Diversity in Unity: Indonesia's Process of Political Decentralisation and its Effects on Conflicts," Verfassung und Recht in Übersee [Law and Politics in Africa, Asia and Latin America] 39, no. 3 (September 2006): 292-305.

20 In a modern party democracy, federalism can work as a system of checks and balances only if the political parties, too, are federalised. For this reason, German law requires the political parties to be subdivided into federal divisions. In political reality, the state level is very strong in most political parties, and party discipline will not stop a state division of a party from criticising measures that the self-same party installs on the federal level if they feel that that measure violates the interests of their given federal state. For Indonesia, the idea of decentralised parties is advocated by Muhammad Rifqinizamy Karsayuda, "The Decentralization of Political Parties Through the Institutionalisation of the Local Political Parties," Constitutional Review 2, no. 1 (2016): 77-102. 
only but is present everywhere in the country. So, if Indonesia, after more than seven decades of independence, feels that the central state and nation are established, well-rooted and settled to an extent that regional diversity can be given a greater weight in public and political life, then the regional governments and their nationwide representation, the Regional Representative Council, are good starting points for such a development. One idea would be to give the Regional Representative Council real powers. An example could be the federal chamber in Germany, the Bundesrat: It has to be consulted in all legislative projects of the first chamber (and in the election of some high-ranking state officials), but its assent is necessary only in those matters that have a special relevance for the federal states and which are precisely defined in the text of the German Grundgesetz. In all other matters, the Bundesrat can only exercise a suspensive veto; if the Bundesrat refuses its assent, its veto can be overruled easily in the first chamber. Strengthening the nationwide representation of the regions as a first step has the advantage that such a measure has its effects predominantly on the central level and not so much in the regions themselves and therefore does not encourage secessionist ideas.

\section{THE PRESIDENT AND THE PRESIDENTIAL FORM OF GOVERNMENT}

The Constitution defines Indonesia's form of government as presidential, and this special feature cannot be changed even by constitutional amendment, as article 37(5) sets out. Typologically, the Indonesian form of presidentialism belongs to the 'pure' (or, in other words, 'extreme') presidential systems because the President is not only the head of state, but at the same time the head of government. According to article 17 , there are only ministers, ${ }^{21}$ but no prime

\footnotetext{
${ }^{21}$ In this context, art. $17(4)$ is strange for a German reader because in Germany a ministry is established and terminated by an organisational act of the government. The leading case in Germany is: Judicial Review of an Order of the Prime Minister to Unite the Ministries of the Interior and of Justice, Decision of North-Rhine-Westphalia Constitutional Court no. VerfGH 11/98 (The Constitutional Court of the Federal State of North-Rhine-Westphalia), accessed January 28, 2021, https://www.vgh.nrw.de/rechtsprechung/entscheidungen/1999/990209_11-98.pdf. In a presidential system, however, the influence that art. 17(4) gives to parliament is probably an important checks and balances factor.
} 
minister. In 'moderate' presidentialism, the executive has two power centres: the President on the one hand and the government, led by a prime minister, on the other. In the Indonesian 'pure' presidentialism, the executive is uniform and has only one centre: the President. Therefore, the Indonesian presidential form of government resembles closest the presidentialism in the US.

This choice is exactly the opposite of what the German Constitution says. In the Grundgesetz, the Federal President is merely a symbolic figure, the political power centres being the Parliament and the chief of the Federal Government, the so-called Federal Chancellor. After the Nazi dictatorship (1933-1945), the general interpretation was that the strong President of the interwar constitution, the so-called Weimar Constitution (1919-1933), had helped the Nazis into power. ${ }^{22}$ In order to prevent the repetition of such a constellation, the Grundgesetz chooses a parliamentary system with a symbolic head of state. Indonesia after independence, on the other hand, took the same choice as many other freshly decolonised countries and entrusted a strongman with the creation of a state and a nation. After independence, this strongman was seen as a guarantee for the necessary stabilisation of the state and the nation. Both choices were well founded in their day, but were made more than 70 years ago. Both countries are wise not to let that historical choice stand in the way if today or tomorrow's needs may require a different power arrangement.

\subsection{Popular and Parliamentary Election of the President}

The President of the Republic of Indonesia is elected by the people [article 6A(1)], which is in line with the position of the President. An office that holds this amount of political power requires a direct popular vote for legitimacy. Therefore, in all presidential and mixed systems in the world, the President is elected by the people.

However, there seems to be a contradiction in the Indonesian Constitution. The people elect the head of state only in the event of a

${ }^{22}$ In Germany, there is a vast literature on the role of the President in that process. The most recent example is Heinrich August Winkler, Wie wir wurden, was wir sind. Eine kurze Geschichte der Deutschen [How We Became What We Are. A Short History of the Germans] (Munich: C.H. Beck, 2020), 61-85. 
regular election. If extraordinary elections become necessary because both the President and the Vice-President can no longer fulfil their duties, it is not the people who elect the new President and Vice-President, but the People's Consultative Assembly [article 8(3)2], which is a sort of joint organ of the People's Representative Council and the Regional Representative Council (article 2). There is no clear reason why the power to elect is given to the people in regular elections, but to the People's Consultative Assembly in extraordinary elections. One reason may be the time factor. If the offices of both the President and the Vice-President become vacant suddenly, an election by the People's Consultative Assembly can be organised quicker than a nation-wide election. Yet, this argument is not convincing. There is no rush because article $8(3)_{1}$ provides for a caretaker presidency, which may govern the country until nation-wide presidential elections are organised.

Another argument may be made against an election by the People's Consultative Assembly. The President holds a considerable amount of power and therefore needs an impeccable democratic legitimacy. A direct election by the people creates such a legitimacy. An election by the People's Consultative Assembly, on the other hand, can provide a President only with an indirect and therefore insufficient legitimacy - even more so as the members of the People's Consultative Assembly possess various degrees of democratic legitimacy since some are elected by the people in nation-wide elections and others are elected on a regional basis. This is exactly the reason why article 54(1), (3)-(4) of the German Grundgesetz provides for an organ quite similar to the People's Consultative Assembly, the so-called Bundesversammlung [Federal Assembly], as the forum of the election of the Federal President. The Bundesversammlung consists of all MPs of the federal first chamber and an equal number of citizens delegated proportionally by the parliaments of the federal states; its only task is to elect the Federal President. This construction was chosen because it gives the Federal President only a weak democratic legitimation, which again is 
seen as a guarantee that the Federal President remains a symbolic figure and does not develop into a political power centre. ${ }^{23}$

\subsection{Checks and Balances in Indonesia's Presidential System}

Due to the Nazi past, Germans are suspicious of presidential systems, thinking that they tend to be close to, or at least prone to lead to, dictatorship. However, an analysis of the Indonesian Constitution shows that 'pure' presidentialism, too, is not without checks and balances. The first safety belt in Indonesia is that a President cannot have more than two subsequent periods (article 7). In theory, there is the danger that a strongman, after two terms as President, may use a puppet to replace him in the office of the President, and then return to office for another two terms. One example of such a practice is Russia and the way Putin used Medvedev. ${ }^{24}$ This danger may be reduced by allowing an absolute maximum of two terms, i.e., by dropping the "subsequently" from article 7. But even then, this theoretical danger does not stop entirely because a two-terms-maximum rule would not stop a strongman who uses several subsequent puppets as Presidents. In the end, the limitation of the number of presidential terms is an important safeguard against dictatorship, but the true guarantee is not a maximum number of terms but a political culture that does not tolerate a President to become a dictator.

Another important factor in the system of checks and balances is the discharge procedure. In a parliamentary system, the head of government depends on parliament, and if parliament no longer supports her or him, it may replace one prime minister with another one. The President of the Republic of Indonesia, who is elected by the people and not by parliament, does not owe political responsibility to parliament, at least not in the sense that parliament has the power to terminate the President's office for political reasons. Nevertheless, there has to be a mechanism to react to possible

23 Klaus Stern, Das Staatsrecht der Bundesrepublik Deutschland [Constitutional Law of the Federal Republic of Germany] 7 vols., $1^{\text {st }} / 2^{\text {nd }}$ ed (Munich: C.H. Beck, 1978-2001), 179-201.

${ }_{24}$ There are more examples in political practice, e.g., Yugoslavia's dictator of the 1990s, Milosevic, who, after two terms as President, jumped to various offices, having puppets on the President's seat. 
political abuse of power by the President. ${ }^{25}$ The Indonesian Constitution created such a control mechanism in the form of the discharge procedure (articles $7 \mathrm{~A}-7 \mathrm{~B}$ ).

The Indonesian discharge procedure is a combination of political and legal elements. The legal element consists in the reasons for the discharge: a discharge procedure requires proof of a violation of law in the form of treason, corruption, bribery, other felonies or disgraceful acts, or that the President no longer meets the legal requirements for that office, e.g., if she or he lost Indonesian citizenship. The political element is the decision by parliament whether or not to act on the President's misbehaviour, initiating the discharge procedure. Even if it is proven that there is a reason for discharge, the Constitution does not make a discharge procedure compulsory, but leaves the decision to the political discretion of the People's Representative Council. One weak element is the reason of a "disgraceful act" [perbuatan tercela, articles $7 \mathrm{~A},{ }_{7} \mathrm{~B}(1)$, (5)]. It is very vague, and that may make it open to abuse. A parliament that wants to get rid of the President may identify some minor fault in the President's behaviour as a "disgraceful act". The vagueness of the term makes it difficult for the Constitutional Court, too, to give it solid contours. On the other hand, a "disgraceful act" is, in its vagueness, open to changes in the social values of the society so that a behaviour which was deemed acceptable in 1945 may appear disgraceful today - or vice versa.

The Indonesian Constitution aptly distributes the powers to discharge a President among political and legal institutions. The decision whether to initiate a discharge procedure is a political one and therefore in the hands of a pre-eminently political organ: the People's Representative Council [article ${ }_{7} \mathrm{~B}(1)$ ]. The examination whether the grounds for a discharge can be proven is of a legal nature and therefore given to a judicial institution:

\footnotetext{
25 If a president is elected by the people, the logical way to terminate the president's term would be a recall by the people. The constitutions of some German federal states have provisions on recalling the government by way of referendum, but in political practice, there never has been a recall referendum, not even an initiative for such a referendum.
} 
the Constitutional Court [articles $\left.7 \mathrm{~B}(1)-(5),{ }_{24} \mathrm{C}(2)^{26}\right]$. Comparatively, some constitutions involve the Supreme Court; the examination whether a president committed a criminal offence requires expertise in criminal rather than constitutional law, and this expertise can be found in the Supreme rather than the Constitutional Court. ${ }^{27}$ Finally, the decision to remove the President from office is again a highly political one. However, this decision is not given to the People's Representative Council but to the People's Consultative Assembly in which the representatives of the People's Representative Council - and thus the central level - have a majority of at least three-fourth [article $22 \mathrm{C}(2)$ ]. By setting the political decisions about the initiation of the procedure and about the discharge on two at least partly different organs, the Indonesian Constitution separates the function of the 'accusation' (People's Representative Council with a two-thirds majority) from the function of the 'judge' (People's Consultative Assembly with a two-thirds majority in the presence of at least three-fourth of all members), which is a requirement of natural justice. Article ${ }_{7} \mathrm{C}$ makes sure that the President cannot paralyse the discharge procedure.

In sum, the Indonesian discharge procedure is a balanced system of checks and balances composed of both legal and political decisions, which are settled on the appropriate organs. As a result, the threshold to remove a President from office is high. Given that the President is to guarantee the stability of the entire Indonesian state, the choice to make her or his removal from office difficult is quite understandable. All presidential forms of government do not allow to remove the chief of the executive easily, as the example of the US shows. During the more than 200 years of American history, several impeachments were started, but none was ever successful. ${ }^{28}$

26 Art. 61 Grundgesetz.

${ }_{27}$ Examples are the discharge procedure against the President in Russia, Romania and Moldova for high treason (Russia, Romania), a serious crime (Russia) or any criminal act (Moldova).

28 Arguably, the impeachment procedure against President Nixon in 1974 would have been successful, but Nixon resigned before the completion of that procedure. Insofar, the initiation of the impeachment procedure had achieved its goal: to remove from office a president who had abused his power. 
There are two points where the system of checks and balances concerning the President might be improved: the declaration of war and the state of emergency. The President declares war with the approval of the People's Representative Council [article 11(1)]. There is no rule for the case that the People's Representative Council can no longer convene, as may happen in the case of a sudden attack. Article 22 grants the President special powers "in the event of a compelling exigency". This term is very vague, compared to many other constitutions that define more precisely the situations in which special powers are granted. However, it is not easy to define these situations in a way which on the one hand is precise enough to prevent abuse and on the other hand is sufficiently flexible to deal with all sorts of unforeseen and unforeseeable situations. Another point requires more precision. Article 22(3) states that an emergency government regulation that fails to obtain the approval of the People's Representative Council "must be revoked" [harus dicabut]. The verb "must" (harus) together with the patient-focus verb "dicabut" suggests that a separate act of revocation is necessary, but article 22(3) does not define who is obliged to revoke, nor what happens if the revocation does not take place. It would be much easier if an emergency government regulation not endorsed by the People's Representative Council ceased to be valid from the moment of the 'no' in parliament, without the necessity of any further act of revocation. A rewording of article 22(3) could guarantee such an automatism.

\section{THE LEGAL SYSTEM}

The Indonesian Constitution does not have a comprehensive regulation of the legal system, the sources of law and their hierarchy. Just like the German Grundgesetz and many other constitutions, the Indonesian Constitution presupposes the existence of a hierarchy of sources of law ${ }^{29}$ and contains rules on only some aspects. ${ }^{30}$

29 Especially art. I of the Transitional Provisions.

30 Comparative constitutional law shows us that usually constitutions after a universal change of system find it necessary to introduce a comprehensive regulation of the hierarchy of the sources of law. A good example are 
To start with, for a 'Rechtsstaat' - this German word is a more appropriate translation of "negara hukum" in articles 1(3), 28I (5) than the English 'rule of law' is - the existence of a good legal system with a welldefined system of sources of law is essential. In a 'Rechtsstaat'/'negara hukum', all relevant questions are regulated by the law, and the law is binding upon all. This is the essence of 'Rechtsstaat'/'negara hukum'. This central role of the quality of the legal system for the 'Rechtsstaat'/'negara hukum', however, does not mean that all details of the legal system must be dealt with on the level of the Constitution. As both the Indonesian and the German constitutions show, it is very well possible to entrust the appropriate organs, first of all the legislature, with the creation and improvement of the legal system without formulating many constitutional preconditions.

For the smooth operation of the hierarchy of sources of law, a judicial norm control is crucial. Indonesia chose a wise way to distribute the powers for this norm control. The Constitutional Court reviews formal laws against the Constitution [article $24 \mathrm{C}(1)$ ], whereas the Supreme Court controls whether sub-legal pieces of legislation are in harmony with laws [article $24 \mathrm{~A}(1)$ ]. Other states concentrate all forms of norm control with the Constitutional Court, as e.g., Hungary did for quite a while (1990-2012). ${ }^{31}$ The Indonesian way is better because it attributes every court its proper function. The Constitutional Court, whose task it is to adjudicate on the Constitution, can do just that when examining whether a law is in harmony with the Constitution. In these cases, the standard of scrutiny is the Constitution, and the Constitution is exactly what the Constitutional Court specialises in. On the other hand, the standard of scrutiny of sub-legal pieces of legislation is not the Constitution but laws, and the ultimate interpreter of laws is the Supreme Court. Hence, in each case the Constitutional Court and the Supreme Court are awarded the tasks they do best. ${ }^{2}$

the post-socialist constitutions: Since they do not want to continue the socialist system of sources of law, but strive to establish a new system, they deal with this question in detail.

$3^{1}$ Constitution of the Republic of Hungary, $\int 32 / A$ (valid between $23^{\text {rd }}$ October 1989 and $31^{\text {st }}$ December 2011).

32 On this division of labour between constitutional and supreme courts in a comparative perspective, see Herbert Küpper and Attila Vincze, eds., Verfassungsgerichte und Obergerichte in Mitteleuropa [Constitutional Courts and Supreme Courts in Central Europe] (Frankfurt/M.: Peter Lang, 2018). 
In connection with the Constitutional Court, it is surprising for a German reader that article $24 \mathrm{C}(5)$ does not require legal knowledge from a member of the Constitutional Court. In Germany, every judge, including Constitutional Justices, is required to hold a degree in law. However, there are more countries where a formal law degree is not always necessary for a judicial function (e.g., Switzerland) or for a post in a supreme or constitutional court (e.g., United Kingdom). Furthermore, article $24 \mathrm{C}(5)$ allows "statespersons" [negarawan] to be a member of the Constitutional Court. In Germany, we are quite reluctant to allow politicians to become judges at the Constitutional Court. Our experience is that (an ex-) politician finds it hard to develop the neutrality that is required to scrutinize a measure, e.g., a law, which she or he may have contributed to enact. In order to prevent such conflicts of interest, in Germany we usually observe a non-official cooling period.

Another astonishing point for a German reader is to find that there is no rule on international law. There is, of course, article 11 on international treaties. But the Indonesian Constitution is silent about the domestic role of general (customary) international law. Article 25 of the German Grundgesetz declares that "the general rules of international law are a part of federal law", and as such, they "prevail over statutes and create immediate rights and duties for the inhabitants of Germany". In 1949, after the end of the Nazi dictatorship, this incorporation of the general rules of international law into the domestic German legal system, in the rank below the Constitution, but above statute, was seen as a guarantee against future dictatorships. For the same reason, practically all post-socialist constitutions of Eastern Europe define in some way or other the role of international law as a domestic source of law. Today, with dictatorship not being a problem of actuality, the German clause is interpreted as a guarantee of an open and internationally integrated Germany, which is an important aspect for a country with an economy heavily reliant on exports. 


\section{DEMOCRACY}

The Indonesian presidential system is based on democracy. At the same time, democracy is one of the five principles of Pancasila. Consequently, article 1(2) states people's sovereignty. A German reader notices two striking features about Indonesian democracy.

\subsection{Direct Democracy}

First, there is no mention of direct democracy. Given that the fourth principle of Pancasila defines democracy as a representative one, it is not surprising that the Indonesian Constitution concentrates on representative democracy. It is open to debate, however, whether Pancasila and the Indonesian Constitution actively forbid direct democracy or simply do not deal with the question, leaving it to the law-maker to decide. The German Grundgesetz is rather silent on direct democracy as well, and for many years there have been robust discussions about the introduction of referenda on the federal level. After 1945, the standard argument was that referenda contributed to the decline of the democracy in the Weimar period (1919-1933) and were a plebiscitarian instrument in the hands of the Nazi dictators (1933-1945). Recent research shows that the facts are not this simple. ${ }^{33}$ In the federal states and on the local level, the situation is completely different, and the people quite often can decide questions of state legislation or in local affairs. So far, the German experiences with direct democracy have been positive rather than negative. One reason is a very precise pertinent legislation. Every federal state has its own system. This makes Germany a big laboratory for different forms of direct democracy, where gradually best practices can evolve.

\subsection{Party Monopoly}

Second, several provisions on the candidates for political office monopolise the nomination of candidates in the hands of political parties:

33 The most comprehensive analysis is given by Peter Neumann, Sachunmittelbare Demokratie [Direct Democracy] (Baden-Baden: Nomos, 2009). 
President and Vice-President [articles 6A(2), 8(3)2] and the members of the national and regional parliaments [article $22 \mathrm{E}(3)$ ]. On the other hand, parties are banned from the elections of the members of the 'second chamber', the Regional Representative Council, where candidates must be individuals [article $22 \mathrm{E}(4)$ ]. The latter may help the Regional Representative Council to be a true representation of regional interests and not be dominated by political parties. As far as the President, the Vice-President, the People's Representative Council and the regional parliaments are concerned, the reason for the party monopoly is not obvious. The result of this rule is that there cannot be any independent candidates and therefore no independent Presidents or MPs.

It is true that in Germany, where we do not have a formal party monopoly, independent candidates are not too frequent, and they are voted into office even less frequently, but at least there is the theoretical possibility. If the people wish to be represented by someone who does not belong to any party, then why should this democratic wish be limited by rules that favour partyism?

\section{ONE AND ONLY GOD AS A BASIS FOR THE STATE}

In Indonesia, the belief in a "one and only God" [Ketuhanan Yang Maha $E s a]$ is the first principle of Pancasila and as such the basis for the sovereignty of the people (Constitutional Preamble) as well as of the state [article 29(1)]. These two provisions seem to suggest that monotheism is compulsory in Indonesia. Such an interpretation would be in conflict with the freedom of religion as set out in articles $28 \mathrm{E}(1)-(2), 28 \mathrm{I}(1)$ and $29(2)$. In Indonesia, there are many followers of non-monotheist religions like traditional societies with their animism, Hindus or the adherents to the various Chinese religions, ${ }^{34}$ and of course there are persons who choose not to believe at all (negative freedom

\footnotetext{
34 As a result of the pertinent debates in Indonesia, Confucianism was adopted as a religion acceptable in the light of Pancasila in the early $21^{\text {st }}$ century.
} 
of religion). ${ }^{35}$ These groups may be alienated if monotheism is forced upon them, which would violate their freedom of religion.

This conflict can be avoided if the references to a "one and only God" are interpreted as symbolical, as the Indonesian discussion shows. ${ }^{36} \mathrm{~A}$ noncompulsory interpretation is aided by article 9(1), which allows for the Presidentelect to choose between a religious oath or a non-religious pledge. This shows that the individual may choose and that nobody is forced to follow a belief in a "one and only God". On the other hand, national education has to aim at "enhancing faith and piety" [article 31(3)]. Just like the references to a "one and only God", this compulsory educational goal has the potential to alienate certain populations and individuals. In a society as diverse as Indonesia's, it is always dangerous to make beliefs and values of one part of the people (even if it is the majority) compulsory for everybody. Therefore, the Pancasila values of an inclusive "one and only God" have been used to fight back Islamist assertions that all Indonesians must obey (orthodox) Islamic rules. ${ }^{37}$

This is also the German experience. Germany is a country with long-standing religious heterogeneity. In the past, religious differences triggered long, violent and very destructive wars and civil wars in our country. Therefore, a social norm has evolved in the course of the centuries that religious affiliation is a private matter and that religion is to be kept out of public life. The state in particular is expected to be religiously neutral and to observe strict equality when dealing with religious communities. We see this as a guarantee for the religious peace within German society, and it has worked well during the last two centuries. Given this mindset, the German Grundgesetz does not mention any belief, and it mentions "God" only once: in the Preamble in connection

35 On negative freedom of religion, non-believers and Pancasila see Matti Justus Schindehütte, "Zivilreligion als Verantwortung der Gesellschaft. Religion als politischer Faktor innerhalb der Pancasila Indonesiens [Civil Religion as Societal Responsibility. Religion as a Political Factor within Indonesia's Pancasila]" (Doctoral diss., University of Hamburg, 2006), https://ediss.sub.uni-hamburg.de/handle/ediss/1358\#page=151, accessed January 28, 2021.

${ }_{36}$ One might interpret the monotheism of the Indonesian Constitution as the ideological underpinning of the principle of the unitarian state. In general, monotheist religions and world views tend to be centralist because they advocate the idea that there is only one truth, whereas polytheism accepts the existence of many truths and therefore tends to favour diversity.

37 Yance Arizona, "The Return of Pancasila: Political and Legal Rhetoric Against Transnational Islamist Imposition," Constitutional Review 5, no. 1 (2019): 164-193. 
with the German people's "responsibility before God and mankind". Apart from that, the Grundgesetz guarantees individual freedom of religion and the legal status of the religious communities.

The German concept of a state neutral in religious matter must not be confused with the French laïcité [secularism], which provides for a strict separation between the state and the religious communities. In Germany, the state may - and is expected to - cooperate with the churches. Religious neutrality means equidistance, not a total lack of contact. Article 7 Grundgesetz and the church-related articles of the Weimar Constitution that Article 140 Grundgesetz incorporates elaborate on this special concept. The state must not decide on questions of religion and faith - and therefore must not advocate ideas such as a "one and only God", it must not interfere in the internal affairs of the religious communities, and it must treat all religious communities equally; the latter does not prevent the state from taking into account natural differences such as the number of believers. As a result, religion may be taught in state schools but only to pupils who (or whose parents) accept religious instruction; persons teaching religion in state schools and universities are to be approved of by the relevant religious community (the state only controls whether they fulfil the pertinent legal requirements); labour disputes between the religious community and its priests and other religious staff are not heard by the courts of the state but by ecclesiastical courts; the state collects church taxes on behalf of the churches because this is considered to be a pragmatic solution. ${ }^{8}$ However, these privileges are enjoyed only by the churches that the state incorporated under public law. In principle, any church may apply for incorporation; if the state refuses the church can seek, and will obtain, relief from the Federal Constitutional Court. ${ }^{39}$

\footnotetext{
${ }_{38}$ The religious communities define their respective taxes as a percentage of the income tax. Since the state collects the income tax, it possesses all the necessary data for collecting the church tax as well, and if the religious community asks the state to collect them. The state will comply, keeping a certain percentage of the collected church tax to reimburse its expenses.

39 Jehovah's Witnesses were refused incorporation because government said they were overly critical of the institution state and therefore did not deserve the privileges of incorporation. The Federal Constitutional Court ruled that Jehovah's Witnesses fulfilled the constitutional requirements for incorporation and therefore were entitled to be incorporated: Federal Constitutional Court, decision of 19December 2000, 2 BvR 1500/97, available at https://www.bundesverfassungsgericht.de/SharedDocs/Entscheidungen/DE/200o/12/rs20001219_2bvr150097. html. Accessed January 28, 2021.
} 
This traditional system does not work without problems. The incorporation procedure sometimes forces the state to get involved in the inner organisation of a religious community, ${ }^{40}$ the requirement of a minimum size as a precondition for incorporation discriminates against sects, and Muslim communities find it difficult to conform to the requirements of a certain inner organisation, shaped on the Christian churches, as a prerequisite of incorporation. ${ }^{41}$ In the light of the decisions of the European Court of Human Rights on the privileges of incorporated churches in Greece, ${ }^{42}$ it is highly doubtful whether the German system with its privileges for religious communities incorporated under public law is in conformity with the individual freedom of religion. Nevertheless, the German tradition of an equidistant cooperation between the state and the churches has prevented religious tensions for more than a century.

Given these German experiences with the private nature of religious matters and with the beneficial effect of a neutral state, the Indonesian allusions to a "one and only God" appear problematic to a German reader. From a German perspective, we would fear that these allusions in the Constitution would divide society, instead of uniting it.

\section{HUMAN RIGHTS}

The Indonesian Constitution contains an impressive catalogue of human rights. Many things can be said about the human rights in the Indonesian Constitution, but I would like to limit my comments to two provisions and one more general observation.

40 The most frequent constellation is when existing unitary Jewish communities split into two or more and the new communities request incorporation. The state then has to decide whether the new formation is "Jewish" in a religious sense. The leading case is the decision of the Federal Administrative Court of 27 July 2017, 6 B 40.17, re Jewish communities in the federal state of Saxony-Anhalt.

${ }_{41}$ The example of Austria, which has a similar legal status for religious communities, shows that it is possible for Islamic communities to organise themselves in conformity with the requirements for incorporation. In Austria, the Muslim community was incorporated as early as in 1911.

42 The leading cases are Kokkinakis v. Greece, 25 May 1993, 14307/88; Holy Monasteries v. Greece, 9 December 1994, 13092/87; Manoussakis et al. v. Greece, 26 September 1996, 18748/91. 


\subsection{Powers to Protect Human Rights}

First, article $28 \mathrm{I}(4)$ identifies the government as the principal organ to protect human rights. ${ }^{43}$ In Germany, the executive is, historically, the target of human rights, i.e., human rights were granted so that the individual had a defence against the executive power. German administration and government are obliged to observe the human rights, but the judicial branch is entrusted with their final protection. ${ }^{44}$

\subsection{Everybody's Duty to Respect Everybody Else's Human Rights}

Second, article 28J(1) obliges everybody to respect everybody else's human rights. If we take this provision literally, we very soon arrive at a state of impossibility. When I take a job, this job is no longer available to another person. Therefore, when I make use of my right to work, I limit or even violate the other person's right to work [articles $27(2), 28 \mathrm{D}(2)]$. When I choose my marital spouse, in order not to discriminate against anybody [articles $27(1), 28 \mathrm{D}(1), 28 \mathrm{I}(2)$ ], I would have to take (at least) one spouse of every sex, of every race and ethnic group, of every religion etc. Obviously, such an interpretation of article $28 \mathrm{~J}(1)$ is absurd. 45

The solution seems to lie in the interpretation of the verb "respect" [menghormati] in article 28J(1). To respect other persons' human rights does not mean to avoid every infringement. My mere existence touches upon other individuals' human rights: the air I breathe is no longer available to

43 Zezen Zaenal Mitaqin, "The Strong State and Pancasila: Reflecting Human Rights in the Indonesian Democracy," Constitutional Review 2, no. 2 (2016): 159-188.

44 Some scholars criticise that this creates an unhealthy overweight of the judicial branch over the political branches, a mischief which they describe as 'Richterstaat' [judges' state]. Most recently on this, see Bernd Rüthers, Die heimliche Revolution vom Rechtsstaat zum Richterstaat [The Secret Revolution from the Rule of Law to the Rule of the Judges] $2^{\text {nd }}$ ed (Tübingen: Mohr Siebeck, 2016). Indonesia has experienced a similar discussion since the establishment of its Constitutional Court: Mirza Satria Buana, "Legal-Political Paradigm of Indonesian Constitutional Court," Constitutional Review 6, no. 1 (2020): 36-66; Björn Dressel and Tomoo Inove, "Megapolitical Cases before the Constitutional Court in Indonesia since 2004," Constitutional Review 4, no. 2 (2018): 157-187; Rosa Ristawati and Radian Salman, "Judicial Independence vis-à-vis Judicial Populism," Constitutional Review 6, no. 1 (2020): 110-132.

45 On the problem of constitutional clauses that oblige everybody to respect everybody else's human rights in a comparative perspective, see Herbert Küpper, Einführung in die Verfassungssysteme Südosteuropas [Introduction into the Constitutional Systems of South East Europe] (Vienna/Berlin: Verlag Österreich/Berliner Wissenschaftsverlag, 2018), 689-692. 
my fellow citizens. To "respect" my fellow citizens' human rights much rather means that I behave in a way that everybody's human rights prevail in the best way possible, without unduly limiting my own human rights. There are several dogmatic ways to solve this dilemma. The European Convention of Human Rights resorts to the harmonisation of individual human rights through a regulation necessary in a democratic society. In the Indonesian Constitution, article 28I(5) opens the avenue to this argument. For a German constitutional lawyer, however, the recipe for the delimitation of the spheres of individual freedom is given in article 28J(2). In German constitutional doctrine, parliament has to harmonise conflicting human rights through legislation. Where the human rights of two or more individuals collide, e.g., because the respect for my fellow citizens' human rights would result in the limitation of my own human rights, the law has to draw the line between the human rights of the individuals. Ideally, the law allows as much as possible of both colliding rights. The technique to do so is called "practical concordance" [praktische Konkordanz]. ${ }^{46}$ Given the priority of the law in the realisation of human rights, the duty to respect everybody else's human rights, as is laid down in article 28J(1) of the Indonesian Constitution, is not so much a direct constitutional duty of every individual but much rather a commission to parliament to enact laws that define the degree to which everybody is obliged to respect everybody else's rights. The law-maker draws, in the various laws, the delimitation between colliding human rights. If everybody observes these laws, everybody's human rights can prevail to the extent possible in a society.

46 The term was coined by Richard Bäumlin, Staat, Recht und Geschichte. Eine Studie zum Wesen des geschichtlichen Rechts, entwickelt an Grundproblemen von Verfassung und Verwaltung [State, Law, and History. A Study on the Essence of the Historical Law, Developed on the Basic Problems of the Constitution and Public Administration] (Zurich: EVZ, 1961), 30, and introduced into mainstream doctrine by Konrad Hesse, Grundzüge des Verfassungsrechts der Bundesrepublik Deutschland [Basic Traits of the Constitutional Law of the Federal Republic of Germany] (Munich: C.H. Beck, 1967). The first decision of the Federal Constitutional Court to adopt both the term and the concept was the decision of 17 December 1975, 1 BvR 63/68, https://www.servat.unibe.ch/dfr/bvo41029. html. Accessed January 28, 2021. A good summary of the evolution of the praktische Konkordanz is given by former Constitutional Justice Wolfgang Hoffmann-Riem, "Praktische Konkordanz im Verfassungsrechtsdenken von Konrad Hesse, [Practical Concordance in Konrad Hesse's Thinking about Constitutional Law]" Archiv des öffentlichen Rechts (AöR) 144, no. 3 (2019): 467-489. 


\subsection{Social Rights and the Social State}

Since the end of the $19^{\text {th }}$ century, creating, maintaining and widening a state-run welfare system has been one of the cores of political life in Germany, and the "Sozialstaat" [social state] forms a part of the political and cultural identity of Germany. Astonishingly, the Grundgesetz is not very outspoken about this important feature of political culture. In objective law, article 20(1) Grundgesetz, in its enumeration of the basic principles of the state, includes the social state (next to democracy and federalism); these principles cannot be modified by constitutional amendments [article 79(3)]. The federal states, too, need to be social (as well as republican and democratic) states, as the so-called 'homogeneity clause' in article 28(1) sets out, and Germany may only participate in the European Union as long as that union bears a social (as well as democratic, rule-of-law and federative) character [article 23(1)]. On the subjective side, the German Grundgesetz practically grants no social human rights. ${ }^{47}$ The right to education is, if any, spelled out very indirectly article 7 , and there certainly is no basic right to work, to housing or to health care. When the Grundgesetz was drafted and enacted in 1948/49, a quite universal consensus held that the basic rights of the Grundgesetz should be limited to rights enforceable in court, and social rights were not considered to be enforceable, but deemed "to promise more than the state can keep". ${ }^{8}$ Despite a lively debate, which started in the 1980 , this can still be considered the majority opinion of German politics ${ }^{49}$ as well as constitutional doctrine..$^{\circ}$ The only exception is a subjective right

47 The constitutions of some federal states grant some social rights, most frequently in the field of education and labour. For details, see Anke Klose, Soziale Grundrechte in den Landesverfassungen [Social Basic Rights in the Constitutions of the Federal States] (Frankfurt/M.: Peter Lang, 2003).

$4^{8}$ Georg Brunner, Die Problematik der sozialen Grundrechte [The Problems of the Social Basic Rights] (Tübingen: J.C.B. Mohr, 1971).

49 The German federal parliament is debating on a motion to include children's rights into the Grundgesetz. In principle, this aim is endorsed by most political parties, but there is strong disagreement whether this should happen in the traditional form of 'defensive' civil rights or whether they should include a social dimension.

50 A recent overview of the arguments in this debate is given by Christoph Enders, "Social and Economic Rights in the German Basic Law?" Constitutional Review 6, no. 2 (2020): 190-209; Diego Schalper, Der Schutz der sozialen Grundrechte unter besonderer Berücksichtigung der Rechtslage in der Bundesrepublik Deutschland und in der Republik Chile [The Protection of the Social Basic Rights with Special Regard to the Legal Situation in the Federal Republic of Germany and the Republic of Chile] (Frankfurt/M.: Peter Lang, 2019). The state of the all-European debate is documented by Julia Iliopoulos-Strangas, Soziale Grundrechte in den "neven" Mitgliedstaaten der Europäischen Union: Zugleich eine Einführung in die mitgliedstaatlichen Allgemeinen Grundrechtslehren [Social Basic Rights in 
to the very minimum necessary to survive and lead a societal existence: the Federal Constitutional Court has interpreted the guarantee of human dignity in article 1(1) Grundgesetz to include an individual subjective right against the state to a monthly payment of that minimum amount. ${ }^{51}$

In Indonesia, social justice is the fifth principle of Pancasila and as such is reflected in the Preamble of the Indonesian Constitution. Insofar, the political starting point in Indonesia and Germany is similar: social justice is a central part of the political culture, and the state is seen as one - or the - institution to achieve this goal. In objective law, the high value of social justice is reflected in the fact that the Indonesian Constitution dedicates a separate chapter to social justice, combined with the national economy (chapter XIV). In this chapter, article 34 sets out in more detail the social obligations of the state. From a German perspective, this would be a constitutional definition of the social state.

Unlike the German Grundgesetz, the Indonesian Constitution translates this goal into subjective human rights, too. Such rights are, e.g., the right to pursue one's living in articles $28 \mathrm{~A}$ and $28 / \mathrm{C}$, the right to work in articles $27(2)$ and $28 \mathrm{D}(2)$, the right to prosperity, residence, a healthy environment and health care in article $28 \mathrm{H}(1)$ as well as to social security in article $28 \mathrm{H}(3)$, the right to education in article $31(1)$, or the child's right to protection in article $28 \mathrm{~B}(2)$. By their dogmatic nature, some of these rights are traditional civil rights designed not to give the bearer an enforceable claim against the state but the power to fight off interventions by the state, other rights are rights to equal access to certain positions. These rights are not problematic in the perspective of the traditional German perception of social rights, as described above.

the "New" Member States of the European Union: An Introduction into the General Theory of Basic Rights of the Member States] (Baden-Baden: Nomos, 2019).

${ }_{51}$ First in its decision of 18 June 1975, 1 BvL 4/74, https://www.servat.unibe.ch/dfr/bv040121.html. Accessed January 28,2021 . The most recent leading case concerns the social aid reform: decision of 9 February 2021,1 $\mathrm{BvL} 1 / 98,1 \mathrm{BvL} 3 / 09$ and $1 \mathrm{BvL}$ 4/og, available at the website of the Federal Constitutional Court https://www. bundesverfassungsgericht.de/SharedDocs/Entscheidungen/DE/2010/02/ls20100209_1bvloo0109.html. Accessed January 28, 2021. 
For traditional German constitutional doctrine, the truly social rights, i.e., the rights that grant the individual a claim to demand certain goods or services from the state, are difficult to handle. Given the wording of the respective provisions, truly social rights appear to be for instance the right to work and the ensuing livelihood in articles $27(2)$ and $28 \mathrm{D}(2)$, the rights enshrined in article $28 \mathrm{H}$, the right to education in article $31(1)$ or children's right to protection in article $28 \mathrm{~B}(2)$. A German constitutional lawyer would ask two questions: (a) who is the addressee of these rights, i.e. whose obligation is to fulfil the claims arising from those rights?, and (b) which is the procedure in which the owner of the rights can oblige the addressee to fulfil their obligation?

The answer to question (a) is quite simple. The right to education is directed against the state, as article 31(3)-(5) sets out in detail. The other social rights, as any human right, oblige the state, and the state is responsible for their enforcement, as article $28 \mathrm{I}(5)$ makes clear. In the case of children's rights, the parents may be obliged, next to the state, but in the end the state is responsible.

The answer to question (b) is less simple. The constitutional way to put the social rights into reality is legislation, as article $28 \mathrm{I}(5)$ sets out. But what happens if the state does not enact the pertinent laws, or if they are insufficient and provide the individual with less than the constitutional right promises? Can I, as a private individual, sue the state with the aim of obliging it to build houses or create jobs? Or can I sue the state for employment or shelter for myself? The Indonesian Constitution does not contain any mechanisms - other than the political mechanism of voting into power a party that promises to fulfil the constitutional promises $^{52}-$ that individuals may use in order to enforce their social rights. In many West European countries such as France, Great Britain, the Netherlands, or Nordic countries, political mechanisms count as a sufficient guarantee.

\footnotetext{
${ }^{2}$ In practice, Indonesia's authoritarian constitutionalism in the economic sphere seems to be the - extra-legal - mechanism to create social justice. For further detail, see, Stefanus Hendrianto, "Constitutionalized But Not Constitute: The Case of Right to Social Security in Indonesia," Constitutional Review 6, no. 2 (2020): 241-281.
} 
German constitutional doctrine, however, would consider a right without a legal enforcement mechanism as defective and the law granting such a right as a lex imperfecta. ${ }^{53}$

This German focus on judicial enforceability can be explained by a look at the German past.54 The Weimar Constitution (1919-1933) enumerated many social rights without providing for an enforcement mechanism. After 1945, this was interpreted as one reason why so many citizens were disappointed with democracy and voted for the Nazis. Under the Nazi dictatorship, the citizen was reduced to a mere object of state power with no means of protection against the state. Given these historical experiences, the described consensus arose after 1945: all legal positions that the Grundgesetz grants must be enforceable, which eo ipso led to the conclusion that promises which could not be made enforceable, such as social rights, should remain outside the Grundgesetz.

\section{TECHNICAL ISSUES}

\subsection{The Repetitiveness of the Indonesian Constitution}

Some questions are regulated by identical rules in several articles. Such repetitions are especially frequent with regard to human rights. To name some examples, everybody's freedom of association, assembly and expression is set out in article 28 as well as in article $28 \mathrm{E}(2)$ ), (3). Everybody's right to life is enshrined in articles $28 \mathrm{~A}$ and $28 \mathrm{I}(1)$, and the freedom from torture in articles 28G(2) and 28I(1). Both articles 27(3) and 30(1) guarantee every citizen's right to participate in the defence of the country. Other repetitions differentiate between the right of everybody and the right of every citizen, such as equal treatment and freedom from discrimination [everybody: articles $28 \mathrm{D}(1), 28 \mathrm{I}(2)$; citizens: article $27(1)]$, the right to work and a decent remuneration [everybody: article $28 \mathrm{D}(2)$; citizens: article $27(2)]$ or the right to acquire education [everybody: article $28 \mathrm{C}(1)$; citizens: article

53 On the Indonesian discussion about enforcing social rights the political or the legal way see Andy Omara, "Enforcing Nonjusticiable Rights in Indonesia," Constitutional Review 6, no. 2 (2020): 311-337.

54 See 7.1. 
31(1)]. Another repetition differentiates between everybody's and inhabitants' freedom of religion, belief and conscience [everybody: articles $28 \mathrm{E}(1)-(2)$, 28I(1); inhabitants: article 29(2)]. Finally, the individual aspects of citizenship are not repeated but dispersed over several articles [articles $26,28 \mathrm{D}(4)$ and $28 \mathrm{E}(1)]$, which makes it necessary to read all these provisions together when dealing with citizenship.

Repeating the same or nearly the same rule in different articles of a constitution is not a bad thing in itself. It is in stark contrast, however, to the legislative technique of the German Grundgesetz and German laws in general, which very carefully avoid repetition and instead contain a large number of cross-references. Setting out the same rule in several appropriate places, as the Indonesian Constitution does, may make it easier to understand and to interpret the text, especially for citizens without a legal background. In Germany, there is widespread criticism against the described legislative technique, culminating in the Civil Code: the large number of cross-references makes that piece of legislation difficult to understand even for a trained lawyer. ${ }^{55}$ On the other hand, there is the danger of inner contradictions. Especially amendments have to be very careful to introduce the same changes in all the places where one and the same rule is set out. This requires a high degree of legislative circumspection.

\subsection{Terminological Questions}

Various provisions of the Indonesian Constitution deal with institutional independence, and they use in sum five different expressions for this independence. The Preamble describes the independence of the state from colonial rule with the term "kemerdekaan", and the same term is used to describe some human rights, i.e., the freedom of association, assembly and expression in article 28, the freedom of thought and conscience in article 28I(1), and the freedom of religion in article 29(2). Not "kemerdekaan", but "merdeka" qualifies the judicial power in article 24(1). The term "mandiri"

55 A good example of the criticism is Wolfgang Kallwass and Peter Abels, Privatrecht [Private Law] $24^{\text {th }}$ ed (Munich: C.H. Beck, 2021), 21-29. 
describes the status of the Election Commission [article 22E(5)], of the Financial Audit Board [article 23E(1)], $5^{6}$ of the Judicial Commission [article ${ }_{24} \mathrm{~B}(1)$ ] and of the economy [article $33(4)$ ]. There are two more terms of European origin. Regional governments enjoy "otonomi" [articles 18(2), (5), (6), $22 \mathrm{D}(1),(2),(3)]$, and the Central Bank is given "independensi" in article $23 \mathrm{D}$.

In German constitutional theory, as well as in the practice of the Federal Constitutional Court, one word should always mean the same thing throughout the entire text of the constitution, and on the other hand, two different terms should mean something different. If we apply this German doctrine to the Indonesian Constitution, "kemerdekaan", "merdeka", "mandiri", "otonomi" and "independensi" all mean something different. One way of differentiating them might be the subject of the freedom, e.g., "otonomi" is a special word for the status of the regional governments. Another differentiation may concern the degree of freedom; in this case, constitutional interpretation would have to bring these terms or at least some of them into a hierarchy of freedom.

There is one terminological difference which may cause problems. The courts and judges are "merdeka", whereas the watchdog of judicial independence, the Judicial Commission, is "mandiri". Does the watchdog enjoy more or less autonomy or freedom that the object of its guarantees? Since the independence of every single judge as well as of the judiciary on the whole is one of the core values of 'Rechtsstaat'/'hukum negara', "merdeka" must denote the highest possible degree of non-interference. Besides, it is questionable if a Judicial Commission whose members are not elected by the judiciary but appointed by the executive and legislative branches [article ${ }_{24} \mathrm{~B}(3)$ ] can be truly independent from these two branches and guarantee the judicial branch's independence. On the other hand, many states in South and South East Europe make rather negative experiences with their

${ }^{56}$ A material guarantee of that autonomy is that the members of the Board may elect their own leadership according to art. $23 \mathrm{~F}(2)$. 
judiciary-elected judicial councils because they try to enforce conformity and thus exercise undue pressure on the individual judge's independence..$^{57}$

\section{SOME FINAL REMARKS}

The Indonesian Constitution is a remarkable and very rich document. My previous remarks cannot but scratch on the surface and draw the attention to some points that strike a reader from a different constitutional and legal culture.

On the basis of this constitutional document, Indonesia has lived for more than seven decades in independence. Germany's Grundgesetz, too, has seen seven decades of peaceful and stable development and has also mastered the fundamental challenge of reuniting the two German states in 1990. My wish is that both constitutional systems take the chance and learn from each other to face the challenges of the future, among which are, inter alia, demographic questions, globalisation, the digital revolution and climate change. The more we learn from each other, the better are we equipped to make the proper choices.

\section{BIBLIOGRAPHY}

Arizona, Yance. "The Return of Pancasila: Political and Legal Rhetoric Against Transnational Islamist Imposition." Constitutional Review 5 no. 1 (2019).

Bundesministerium der Justiz und für Verbraucherschutz [Federal Ministry of Justice and Consumer Protection]. "Basic Law for the Federal Republic of Germany of $23^{\text {rd }}$ May 1949." Last amendment by the Act to Amend the Basic Law of $15^{\text {th }}$ November 2019. Accessed $28^{\text {th }}$ January 2021. https://www. gesetze-im-internet.de/englisch_gg/.

Bäumlin, Richard. Staat, Recht und Geschichte [State, Law, and History]. Zurich: EVZ, 1961.

Benda-Beckmann, Franz von. "Verfassungsrechtspluralismus in West Sumatra: Veränderungen in staatlicher und dörflicher Verfassung im Zuge der

57 Küpper, Einführung, 610-614. 
Dezentralisierung in Indonesien [Constitutional Pluralism in Western Sumatra: Changes in the Constitution of the State and of the Villages in the Course of Decentralisation in Indonesia]." Verfassung und Recht in Übersee (VRÜ = Law and Politics in Africa, Asia and Latin America) 35, no. 4 (2002). Brunner, Georg. Die Problematik der sozialen Grundrechte [The Problems of the Social Basic Rights]. Tübingen: J.C.B. Mohr, 1971.

Buana, Mirza Satria. "Legal-Political Paradigm of Indonesian Constitutional Court." Constitutional Review 6, no. 1 (2020).

Bünger, Karl. "Dokumente zur Entstehung der Vereinigten Staaten von Indonesien [Documents on the Creation of the United States of Indonesia]." Zeitschrift für ausländisches öffentliches Recht und Völkerrecht (ZaöRV = Heidelberg Journal of International Law) 13 (1950): 431-473. Accessed August 9, 2020. https://www.zaoerv.de/13_1950_51/13_1950_2_b_431_473.pdf.

Dressel, Björn and Tomoo Inoue. "Megapolitical Cases before the Constitutional Court in Indonesia since 2004." Constitutional Review 4, no. 2 (2018).

Eddyono, Luthfi Widago. "The Unamendable Articles of the 1945 Constitution." Constitutional Review 2, no. 2 (2016).

Enders, Christoph. "Social and Economic Rights in the German Basic Law?" Constitutional Review 6, no. 2 (2020).

Eur-Lex. "Regulation (Eu) 2019/788 of The European Parliament and of The Council.” Aaccessed January 28, 2021. https://eur-lex.europa.eu/legal-content/ EN/TXT/?uri=CELEX\%3A32019Ro788\&qid=1611135454353.

Häberle, Peter. "Verfassungsrechtliche Ewigkeitsklauseln als verfassungsstaatliche Identitätsgarantien [Constitutional Eternity Clauses as Guarantees of Constitutional Identity]." In Völkerrecht im Dienste des Menschen [International Law Serving Man], edited by Y Hangartner and S Trechsel. Bern: Haupt, 1986.

Hendrianto, Stefanus. "Constitutionalized but not Constitute: The Case of Right to Social Security in Indonesia." Constitutional Review 6, no. 2 (2020). 
Hesse, Konrad. Der unitarische Bundesstaat [The Unitarian Federal State]. Karlsruhe: C.F. Müller, 1962.

Hesse, Konrad. Grundzüge des Verfassungsrechts der Bundesrepublik Deutschland [Basic Traits of the Constitutional Law of the Federal Republic of Germany]. Munich: C.H. Beck, 1967.

Hoffmann-Riem, Wolfgang. "Praktische Konkordanz im Verfassungsrechtsdenken von Konrad Hesse [Practical Concordance in Konrad Hesse's Thinking about Constitutional Law]." Archiv des öffentlichen Rechts (AöR) 144, no. 3 (2019). Iliopoulos-Strangas, Julia. Soziale Grundrechte in den "neuen" Mitgliedstaaten der Europäischen Union: Zugleich eine Einführung in die mitgliedstaatlichen Allgemeinen Grundrechtslehren [Social Basic Rights in the "New" Member States of the European Union: An Introduction into the General Theory of Basic Rights of the Member States]. Baden-Baden: Nomos, 2019.

Jun, Uwe. "Der Bundesrat im föderativen System Deutschlands: Vor und nach der Reform 2006 [The Federal Council in Germany's Federal System: Before and After the Reform of 2006]." In Analyse demokratischer Regierungssysteme [Analysis of Democratic Systems of Government], edited by K H Schrenk and M Soldner. Wiesbaden: Verlag für Sozialwissenschaften, 2010.

Kallwass, Wolfgang and Peter Abels. Privatrecht [Private Law]. $24^{\text {th }}$ ed. Munich: C.H. Beck, 2021.

Karsayuda, Muhammad Rifqinizamy. "The Decentralization of Political Parties through the Institutionalisation of the Local Political Parties." Constitutional Review 2, no. 1 (2016).

Kischel, Uwe. Rechtsvergleichung [Comparative Law]. Munich: C.H. Beck, 2015. Klose, Anke. Soziale Grundrechte in den Landesverfassungen [Social Basic Rights in the Constitutions of the Federal States]. Frankfurt/M.: Peter Lang, 2003.

Küpper, Herbert. Autonomie im Einheitsstaat [Autonomy in a Unitarian State]. Berlin: Duncker \& Humblot, 2002. 
Küpper, Herbert. Einführung in die Verfassungssysteme Südosteuropas [Introduction into the Constitutional Systems of South East Europe]. Vienna/ Berlin: Verlag Österreich/Berliner Wissenschaftsverlag, 2018.

Küpper, Herbert and Attila Vincze, eds. Verfassungsgerichte und Obergerichte in Mitteleuropa [Constitutional Courts and Supreme Courts in Central Europe]. Frankfurt/M.: Peter Lang, 2018.

Muttaqien, Zezen Zaenal. "The Strong State and Pancasila: Reflecting Human Rights in the Indonesian Democracy." Constitutional Review 2, no. 2 (2016): 159-188.

Neumann, Peter. Sachunmittelbare Demokratie [Direct Democracy]. BadenBaden: Nomos, 2009.

Neumeyer, Hannah. "Unity in Diversity or Diversity in Unity: Indonesia's Process of Political Decentralisation and Its Effects on Conflicts." Verfassung und Recht in Übersee (VRÜ = Law and Politics in Africa, Asia and Latin America) 39, no. 3 (2006).

Nurjaya, I Nyoman. "Is the Constitutional and Legal Recognition of Traditional Community Laws Within the Multicultural Country of Indonesia a Genuine or Pseudo Recognition?" Constitutional Review 1, no. 2 (2015).

Omara, Andy. "Enforcing Nonjusticiable Rights in Indonesia." Constitutional Review 6, no. 2 (2020).

Ristawati, Rosa and Radian Salman. "Judicial Independence vis-à-vis Judicial Populism." Constitutional Review 6, no. 1 (2020).

Rüthers, Bernd. Die heimliche Revolution vom Rechtsstaat zum Richterstaat [The Secret Revolution from the Rule of Law to the Rule of the Judges]. $2^{\text {nd }}$ ed. Tübingen: Mohr Siebeck, 2016.

Schalper, Diego. Der Schutz der sozialen Grundrechte unter besonderer Berücksichtigung der Rechtslage in der Bundesrepublik Deutschland und in der Republik Chile [The Protection of the Social Basic Rights with Special Regard to the Legal Situation in the Federal Republic of Germany and the Republic of Chile]. Frankfurt/M.: Peter Lang, 2019. 
Schindehütte, Matti Justus. "Zivilreligion als Verantwortung der Gesellschaft. Religion als politischer Faktor innerhalb der Pancasila Indonesiens [Civil Religion as Societal Responsibility. Religion as a Political Factor within Indonesia's Pancasila]." Doctoral diss., University of Hamburg, 2006. https:// ediss.sub.uni-hamburg.de/handle/ediss/1358\#page $=151$. Accessed $20^{\text {th }}$ January 2021.

Schöning, Falk. Föderale Intervention als Instrument zur Bewahrung eines Bundesstaates - Rechtsvergleichende Analyse und völkerrechtliche Legitimation [Federal Intervention as an Instrument to Preserve a Federal State Comparative Analysis and Legitimacy in International Law]. Baden-Baden: Nomos, 2008.

Stern, Klaus. Das Staatsrecht der Bundesrepublik Deutschland [Constitutional Law of the Federal Republic of Germany]. 7 vols., $1^{\text {st }} / 2^{\text {nd }}$ ed., Munich: C.H. Beck, 1978-2001.

Sudrajat, Tedi. "Harmonization of Regulation Based on Pancasila Values Through the Constitutional Court of Indonesia." Constitutional Review 4, no. 2 (2018). The Office of the Registrar and the Secretariat General of the Constitutional Court of the Republic of Indonesia (ed.). The 1945 Constitution of the Republic of Indonesia, Law of the Republic of Indonesia concerning the Constitutional Court. Jakarta: The Constitutional Court of the Republic of Indonesia, 2015. Ward, Ken. "Soeharto's Javanese Pancasila." In Soeharto's New Order and its Legacy: Essays in honour of Harold Crouch, edited by E. Aspinall and G. Fealy. Canberra: ANU Press, 2010.

Wieser, Bernd. Vergleichendes Verfassungsrecht [Comparative Constitutional Law] $2^{\text {nd }}$ ed. Vienna: Verlag Österreich, 2020.

Winkler, Heinrich August. Wie wir wurden, was wir sind. Eine kurze Geschichte der Deutschen [How We became What We are. A Short History of the Germans]. Munich: C.H. Beck, 2020. 